\title{
OPEN COALITION LAW, NECESSITY OR THREAT?
}

\begin{abstract}
From January 1, 2019. Amendments to the Act of July 5, 2018 amending the provisions on trade unions and some other acts apply (almost in full). Amendments to the Polish act are a consequence of the Committee for the Freedom of Association, Labor Law Organizations and the judgment of the Polish Constitutional Tribunal. The main and expected effect of the amendment is the extension of coalition freedom in trade unions. This issue is important not only for the consistency of the legal system with international law, but also for social reasons. Concluding civil law contracts in the place of employee forms of employment is a common practice in Polish conditions. The main problem is that the civil law contract has a purpose other than the employment contract. Contracts of mandate and provision of services are the basis for the implementation of actual and legal activities. Besides, the legislator does not have any real actions aimed at eliminating the defective practice. The text is an attempt to synthetically summarize the motives of the amendment, as well as its effects and tests.
\end{abstract}

Keywords: employment, non-employee employment, trade unions.

\section{OTWARTE PRAWO KOALICJI, KONIECZNOŚĆ CZY ZAGROŻENIE?}

Streszczenie. Od 1 stycznia 2019 r. obowiązują (niemal w całości) zmiany wprowadzone ustawą z dnia 5 lipca 2018 r. o zmianie ustawy o związkach zawodowych oraz niektórych innych ustaw. Zmiany w Polskiej ustawie są następstwem zaleceń Committee on Freedom of Association Labour Law Organizations i wyroku Polskiego Trybunału Konstytucyjnego. Zasadniczym i oczekiwanym skutkiem nowelizacji jest poszerzenie wolności koalicji w związkach zawodowych. Kwestia ta jest istotna nie tylko ze względu na spójność krajowego systemu prawnego z prawem międzynawowym, ale także ze względów społecznych. Zawieranie umów cywilnoprawnych w miejsce pracowniczych form zatrudnienia jest częstą praktyką w polskich warunkach. Zasadniczy problem wiąże się z tym, że umowy cywilnoprawne mają inne przeznaczenie i cel niż umowa o pracę. Umowy zlecenia i świadczenia usług są podstawą realizacji czynności faktycznych i prawnych. Pomimo to, ustawodawca nie podejmuje żadnych realnych działań zmierzających do wyeliminowania wadliwej praktyki. Tekst jest próbą syntetycznego omówienia motywów nowelizacji, a także jej skutków. W prowadzonych badaniach zostanie wykorzystany dorobek literatury i orzecznictwa. Analiza obejmie projekt nowelizowanej ustawy i materiały legislacyjne, a także źródła prawa międzynarodowego.

Słowa kluczowe: zatrudnienie pracownicze, zatrudnienie niepracownicze, związki zawodowe.

*University of Silesia in Katowice, Faculty of Law and Administration; blazej.madrzycki@ us.edu.pl 


\section{INTRODUCTION}

By the Amendment Act of July 5, 2018 (amendment act, 2018. Dz.U.2018.1608), the existing provisions of the Act on Trade Unions were changed. The change consisted in extending the coalition law by allowing a wider group of entities to form and join trade unions than was previously possible. A synthetic description of the introduced changes is presented in the justification to the draft amendment act, which explains that:

The draft regulation changes the provision of Art. 2 clause 1 u.z.z. Pursuant to the new wording of this provision, the right to establish and join trade unions will be vested in persons performing gainful work. As a consequence, a definition of the concept of a person performing gainful work was introduced to the Act on Trade Unions (justification of the bill, 2018).

According to the added definition, a person performing gainful work is

an employee within the meaning of Art. 2 of the Labor Code or a person providing work for remuneration on a basis other than an employment relationship, if he or she does not employ other people for this type of work, regardless of the basis of employment, and has such rights and interests related to the performance of work that may be represented and defended by a trade union.

The introduced changes result in the fact that the trade union will be able to belong to or create such a union (apart from employees within the meaning of Labour Code), e.g. persons fulfilling the obligation on the basis of a mandate contract, provision of services or the so-called self-employment (justification of the bill, 2018).

The amendment, in its own way, is groundbreaking, extending the freedom of the coalition to non-employee entities allows to recognize that in the sphere of collective labor law we already deal with employment law. Another issue is that the application of trade union protection to civil contracts means another approximation of this type of contracts to employee employment.

The amendment is a good opportunity to consider the use of civil contracts as alternative forms of entrusting work. Practical experience as well as analysis of sources indicate that the so-called "Civil law employment" is already (despite the accompanying controversy) a kind of common practice on the Polish labor market. For these reasons, it is worth noting whether the inclusion of civil law contracts in the coalition law is a natural consequence of their application, or only increases the chaos that accompanies them.

\section{POLISH COALITION LAW}

The subjective scope of trade union membership, until the time preceding the entry into force of the amendment in question (i.e. before January 2019), was in fact a repetition of the status in force in the Act of October 8, 1982 - the 
non-binding act on trade unions (trade union act, 1982). As a consequence, it meant that the national legislator, despite numerous changes taking place on the labor market, still in fact lasted in the reality of 1980 s, of the previous century, thus limiting the freedom of creating and joining trade unions to selected groups of entities (Pisarczyk 2019, 125). Already during the effective date of the Act of 1982, it was pointed out that the belief that "there was a need to ensure the right to form trade unions, also the so-called non-employement professional groups, which include self-employed persons working on their own account who do not themselves employ workers" (Zieliński 1986, 282). Nevertheless, in Art. 2 of the Act of 1991, union freedoms (the right to create and belong to trade unions) were vested in employees within the meaning of the Labor Code, as well as members of agricultural production cooperatives, people working under an agency contract, homeworkers, pensioners, unemployed persons, persons ordered to perform alternative service and officers (trade union act, 1991. Dz.U.2015.1881).

The scope of regulation thus established has often been the subject of interest in the literature. There are opinions in the literature according to which the method of granting the right to belong to trade unions in force until the amendment was a kind of legislative discretion of the legislator (Hajn 2010, 176). From the content of the regulations in force at that time, it was difficult to derive an axiological justification for a specific "dosing" of the coalition law to selected entities. In the method of regulation adopted by the legislator, it was also difficult to find clear intentions and explain how to justify the division into full and limited coalition law (Hajn 2010, 176).

\section{THE STATE OF POLISH REGULATIONS AND INTERNATIONAL STANDARDS}

The state of the applicable regulations also gave rise to doubts against the background of international standards (Zieliński 1986, 276-284), namely the Conventions 87 Labor Law Organization (ILO) of 1948 (ILO Convention No. 87). The convention creates the possibility of trade union membership for a wider group of entities than employees within the meaning of Art. 2 Polish Labour Code. An analysis of its provisions may lead to such conclusions. The original versions of the convention also used terms such as 'workers' in the English version and 'travailleurs' in the French language. This fact served as the main argument in the discussion on the compliance of national regulations with international standards. While justifying the need to change the Polish law, it was emphasized that this concept should be interpreted more broadly than the concept of an employee within the meaning of Art. 2 of the Polish Labor Code. Based on this argumentation and accusing the incompatibility with regard to the adjustment of national regulations to international standards, in 2011 the Committee on Freedom of Association Labor Law Organizations (Committee) received a complaint (NSZZ 
Solidarność, complaint) against the Government of the Republic of Poland. It indicates violations of trade union freedoms in Poland consisting in the restriction of trade union freedoms for non-employees. The arguments presented in the complaint met with recognition in 2012, the Committees issued a recommendation according to which:

The Committee requests the Government to take the necessary measures in order to ensure that all workers, without distinction whatsoever, including self-employed workers and those employed under civil law contracts, enjoy the right to establish and join organizations of their own choosing within the meaning of Convention No. 87 (Reports of the Committee on Freedom of Association. Geneva 2012).

\section{WORKER, THAT IS WHO, PARTY OF CIVIL CONTRACT?}

The growing popularity of non-employee forms of employment, at least prima facie, justifies the efforts to extend the coalition law to a wider group of entities than just employees within the meaning of Art. 2. The Labor Code. It becomes problematic whether this scope should cover civil law employment known in Poland - contracts of mandate and provision of services. The different nature of civil contracts than the employee ones may raise doubts in this respect. For these reasons, it is worth devoting a moment more attention to the Committee's recommendations, the more so as they were of interest in the literature.

During the conference Recodification of labor law, which took place in the Polish Senate, the subject of ILO recommendations was discussed. It was then stated that:

The Committee is wrong because conventions no. 87 and 98 use the word "employee" in the authentic English and French texts and this word has the same connotation in these legal systems as in Poland - a person employed on the basis of an employment relationship. The Committee would like to support the scope of freedom of association in a new situation that was not the case fifty years ago, and this requires a decision by the ILO General Conference, not just the interpreting body (Podgórska-Rakiel 2013, 71).

Regardless of the formal comments, there were also doubts about the conclusions of the Committee, and more specifically the scope of analyzes preceding the conclusions about the contradiction of Polish regulations with the Convention (Sobczyk 2018, 214). As already mentioned, it is problematic to include entities employed under civil law contracts with the right to form and belong to trade unions. In its considerations, the Committee came to the conclusion that on the basis of Polish legal regulations the concept of workers is understood too narrowly, which means that persons employed on the basis of civil contracts cannot join and form trade unions. As a consequence, the Committee assumed that the right to belong and establish trade unions should apply to all employees, including those employed under civil contracts. 
The intention to extend trade union protection to broad groups of the employed is indisputable. Only the issue of legal standards is problematic. It cannot be determined from the recommendations how it was concluded that the civil law employment model applied in Poland should fall within the scope of the term worker. It is all the more troublesome as entrusting work under the terms of civil law contracts is specific in Poland. The problem is that the concept of worker is not defined in the Convention and in the recommendations (Sobczyk 2018, 214). Against the background of these circumstances, there is a doubt whether the position of the Committee is too hasty and whether the Committee has sufficient knowledge about the so-called civil law employment (Sobczyk 2018, 214). It seems that the inclusion of civil contracts in the scope of the term worker - contracts of mandate, provision of services - should be preceded by a confrontation of assumptions resulting from the construction of a worker and Polish civil contracts.

Based on the literature, it can be established that the concept of worker comes from Anglo-Saxon doctrine (Musiała 2018, 7-13). In fact, its scope seems to be broader than the concept of an employee as defined by the Polish Labor Code. The only thing is that the workers perform work in conditions similar to those of the employees, and this applies mainly to their entitlements. The literature emphasized that:

The reason for using this extended definition of dependent status is the need to apply protection standards to people who work in conditions similar to employees. The first package of these regulations concerned the application of basic employee standards in relation to: minimum wage, protection against dismissal, protection against exceeding the norms of working time (Musiała 2018, 14).

Consequently, unlike the Polish contractor, the worker has employment rights and performs work under the direction of the principal (Sobczyk 2018, 212). Transferring the meaning to the Polish legal order, it can be assumed that it includes apprentices and volunteers. However, it is not so obvious as for the selfemployed (Musiała 2018, 10).

Doubts as to identifying these concepts become all the more justified when we realize that the use of civil contracts as alternative forms of employment to an employment contract is a specific distortion of the Polish legal system as a cheap form of employment favoring combating unemployment (Kostrzewski, Miączyński 2015). As practice shows, this ad hoc solution has entered the legal system for a long time. Currently, entrusting work under the terms of this type of contract is even provided for in generally applicable acts (act on employment promotion and labour market institution, 2004. Dz.U.2019.1482). Nevertheless, there is no doubt that civil law employment in relation to employment contracts is a much less favorable form for the employee. The character of civil contracts differs in terms of axiology and purpose from employment contracts. Besides, 
limiting the exploitation connected with the use of civil contracts was one of the main reasons for the birth of labor law. Civil law, unlike labor law, does not know such structures as working time standards, rest breaks (daily and weekly), holidays, or general or special protection of employment durability. For these and many other reasons, "work" under a civil contract is much less favorable from the perspective of an "worker" than it is under a contract of employment. Nor is it possible to lose sight of the fact that these employment characteristics are often reflected in ILO Conventions and Recommendations. The essence of the ILO is to establish international labor standards, which should be reflected in the national law of the member states. Despite the significant discrepancies, the Committee almost unreasonably proposed to include the term worker in Polish civil contracts. This type of action may result in the alleged omission of ILO standards, which has already been pointed out in the literature (Sobczyk 2018, 212).

\section{JUDGMENT OF THE CONSTITUTIONAL TRIBUNAL}

Despite the recommendations of the ILO, the Polish legislator did not take any steps to extend the coalition law (Podgórska-Rakiel 2013, 70). As a result of his inactivity, the All-Poland Alliance of Trade Unions (OPZZ), based on the provisions of the ILO Convention, requested the Polish Constitutional Tribunal to review the constitutionality of the provisions of the Polish Act on Trade Unions in the scope limiting the possibility of a union coalition (Zalewski 2012). In its extensive argumentation OPZZ pointed out that "the Committee for Freedom of Trade Union emphasized in many reports that the employment relationship was not a criterion for determining the persons entitled to establish a trade union organization and to act within them". As a result of the submitted application, in 2013 the Constitutional Tribunal shared the position of the OPZZ, finding that the existing restrictions contained in the Act on Trade Unions were incompatible with the Constitution of the Republic of Poland (judgement, 2015. K 1/13). Importantly, neither the judgment nor the justification stated that all employees, including those employed under civil law contracts, should be covered by the coalition law. In the justification of the judgment it was only emphasized that

the unconstitutionality of Art. 2 clause 1 of the Act on Trade Unions consists in restricting the freedom of association in unions for persons performing paid work who do not fall into one of the three categories of entities mentioned in this provision. Therefore, the defectiveness of statutory regulation results from its too narrowly defined subjective scope. It prevents the exercise of the freedom of association in trade unions for a certain group of people who are addressees of the freedom referred to in Art. $59 \mathrm{sec} .1$ in connection with Art. 12 of the Constitution (judgement, 2015. K 1/13 point 11). 


\section{It was also emphasized that}

the Employee, as the subject of freedom of association in trade unions (Article 59 (1) of the Constitution), cannot be identified solely through the prism of the type of legal relationship between him and the employer. In the opinion of the Tribunal, the status of an employee should be - on constitutional grounds - assessed by reference to the criterion of paid work. Against this background, the Tribunal has indicated three premises that define the legal framework for the constitutional understanding of the term employee referred to in Art. $59 \mathrm{sec} .1$ of the Constitution. This concept covers all persons who - firstly - perform a specific gainful activity, secondly, have a legal relationship with the entity for which they perform it, and - thirdly - have professional interests related to the performance of work, which may be collectively protected.

The Court's findings are an important source for the analyzes made. The essence of the judgment boils down to characterizing the set of features of an employed person who acquires the right to join a trade union. Thus, it is not the basis of employment but the terms of employment and the scope of the right and interests that should determine the right to belong. The position formulated in this way is in line with the content of the application, as well as the views of the Committee on Trade Union Freedoms of the Administrative Council of the International Labor Office, which stated that the right to freedom of association under Convention No. 87 should be granted not only to employees, but also to persons who have a different relationship with the employer employment relationship (Freedom of Association. Geneva 2006).

At the same time, a reading of the findings gives grounds to argue that the previously expressed concerns regarding the extension of the coalition law to civil contracts are justified.

\section{THE FORMAL NATURE OF THE REGULATION}

In the context of the introduced changes, the thread of representing members by the union cannot be omitted.

According to Art. 1 of the Act on Trade Unions, "a union is an organization of working people established to represent and defend their rights, professional and social interests". The provision states that membership in a trade union is connected with a sense of security and protection. The scope of trade union rights is individual and collective. Collective interests are realized irrespective of membership, this will be confirmed by regulations and collective labor agreements that apply to all employees, regardless of their affiliation. However, the area of individual representation is different. According to Art. 23 (2) of the Labor Code:

If the provisions of labour law provide for an employer to co-operate with an enterprise trade union in individual cases related to an employment relationship, the employer is obliged to cooperate in such cases with the enterprise trade union representing the employee in respect of 
his membership in the trade union, or in respect of the consenting to the protection of the rights of an employee not covered by the trade union in accordance with the Act on Trade Unions.

In the individual sphere, there is no question of representing the interests of people who provide paid work, who are not employees. The purpose of union membership of non-employees is specified in the Trade Union Act itself. In the amended Art. 1 (1) point 1, defining the concept of a person performing gainful work, the legislator indicated the possession of such rights and interests related to the performance of work that may be represented and defended by a trade union (trade union act, 1991. Dz.U.2019.263). However, careful reading of the regulation raises doubts as to its practical meaning. At the outset, the question arises what types of rights and obligations can be represented and defended by trade unions (Wujczyk 2019, 195). What may be the source of these rights and interests, and who is to evaluate their potential. The analysis of the provision from the perspective of union rights also raises doubts. It is difficult to imagine what actions a company trade union organization will be able to take towards, for example, the principal, in connection with the implementation of a civil contract, by its member-contractor. While in the sphere of individual interests, the Labor Code indicates such regulations, they are absent from the Civil Code.

The above is important because the aforementioned rights and interests (potentially covered by trade union protection) are elements that define the entity entitled to a coalition, therefore it should be assumed that only entities with rights and interests that are subject to protection are covered by the coalition law. In the event of a different inference, the essence of belonging would be a fiction. The lack of real support for the individual interests of non-employees basically rules out the legitimacy of joining trade unions. As a consequence, depriving trade unions of tools enabling the protection of the rights and interests of entities other than employees, but associated in trade unions, limits the willingness to engage in trade union activities (Pisarczyk 2019, 458).

Therefore, the analysis of the regulations gives grounds to claim that it is only a formal basis that requires material implementation through appropriate forms of employment. The legitimacy of such an opinion is confirmed in the legislative process. The draft amending act (justification of the bill, 2018) indicates group interests that are subject to trade union protection. Such content is consistent with the justification of the judgment of the Constitutional Tribunal cited above, where the legal framework for the constitutional understanding of the term employee has been established. Therefore, the wording of the judgment was repeated in the draft. During the legislative process, a change in this respect was introduced. The legislator decided that trade union protection could not be limited only to the protection of rights and interests protected collectively, and finally a structure was adopted according to which it is about rights and interests that "can be represented and defended by a trade union". The justification of this amendment is of great 
importance, as it was emphasized that the proposed content of Art. 1 (1) point 1 (content before introducing the amendment - author's note) "suggests that only collective (group) interests of people performing gainful work were represented and defended by trade unions, while in the light of Art. 4 unions defend both collective and individual interests" (Polish Senat Resolution, 2018). It follows that the deliberate action of the legislator is to provide entities with such rights that may be the subject of individual protection. This, in turn, may suggest that the national legislator should take steps to grant non-employees rights that will be subject to trade union protection. Otherwise, the real goal of the change will never be achieved, because there are no material possibilities to protect the rights of, for example, the contractor by a trade union, even if he is a member of this union.

\section{CONCLUSION}

It was necessary to make changes. The growing popularity of the use of nonemployee forms of employment is a phenomenon visible not only in Poland. Proof of this may be, among others the division into employee and workers. In terms of national legislation, it is all the more important as Poland ranks high among the countries with inflexible forms of employment in the OECD ranking (Matłacz 2017). The effect of this is the growing use of civil contracts - orders, provision of services, often referred to as junk contracts, which adequately reflects their assessment (Grzebyk 2015). In such circumstances, the inclusion of civil contracts in the law should be assessed positively. The problem is that the legislator still does not take any real steps to organize the forms of employment. Over the years, the activities of the legislator, in this respect, could be called cyclical, the changes were mainly limited to imposing social security contributions for civil contracts. At the same time, employees have easier access to health insurance than nonemployees. A socially significant change was the setting of the hourly rate for civil contracts, and this solution is not without criticism (Barański, Mądrzycki 2017, 23-30).

From the perspective of trade unions, the amendment may be an opportunity. Trade unions have acquired an authorization to speak in matters relating to nonemployees, persons employed under civil contracts. It seems that in terms of precarious employment conditions it is an important move, even if it is not yet visible at present. Undoubtedly, this opportunity poses certain challenges for the unions and it is up to the organization to use it. It is important that unions seek to obtain powers to defend individual interests. The lack of real support for the individual interests of non-employees basically rules out the legitimacy of joining trade unions. As a consequence, depriving trade unions of tools enabling the protection of the rights and interests of entities other than employees, but 
associated in trade unions, limits the willingness to engage in trade union activities (Pisarczyk 2019, 458).

Looking from the perspective of the legislator's many years of omissions, a certain concern must also be expressed. It cannot be ruled out that the legislator considers the changes to be sufficient. On the other hand, the recommendation of the Committee to oblige all employees, including those employed under civil contracts, to be interpreted as implicit acceptance of the use of this form of "employment".

\section{BIBLIOGRAPHY}

Barański, Michał. Błażej Mądrzycki. 2017. "Ustalanie liczby godzin wykonania umowy zlecenia lub nienazwanej umowy o świadczenie usług w celu zapewnienia minimalnej stawki godzinowej". Praca i Zabezpieczenie Spoleczne 3: 23-30.

Grzebyk, Piotr. 2015. Analiza orzecznictwa sadowego w sprawach o ustalenie istnienia stosunku pracy. Zatrudnienie pracownicze a zatrudnienie cywilnoprawne. Warszawa: Instytut Wymiaru Sprawiedliwości.

Hajn, Zbigniew. 2010. "Prawo zrzeszania się w związkach zawodowych - prawo pracowników czy prawo ludzi pracy?" In Międzynarodowa konferencja naukowa z okazji trzydziestej rocznicy powstania NSZZ "Solidarność". Edited by Alina Wypych-Żywicka, Monika Tomaszewska, Jakub Stelina. Gdańsk: Fundacja Rozwoju Uniwersytetu Gdańskiego.

Kostrzewski, Leszek. Piotr Miączyński. 2015. "Wszyscy płacimy za śmieciówki”. Gazeta Wyborcza. 20 July 2015. https://wyborcza.pl/1,155287,18390572,wszyscy-placimy-za-smieciowki.html.

Matłacz, Agnieszka. 2017. "FOR: elastyczność zatrudnienia wcale nie oznacza gorszych warunków pracy”. Prawo.pl. 14. December 2017. https://www.prawo.pl/kadry/for-elastycznosczatrudnienia-wcale-nie-oznacza-gorszych-warunkow-pracy,266959.html

Musiała, Anna. 2018. "Reperkusje pojęcia 'worker' w polskim prawie pracy”. Monitor Prawa Pracy 5: 7-13.

Pisarczyk, Łukasz. 2019. Reforma zbiorowego prawa pracy. Próba kodyfikacji a nowelizacja przepisów zbiorowego prawa pracy. Warszawa: Wydawnictwo Wolters Kluwer.

Podgórska-Rakiel, Ewa. 2013. "Rekomendacje MOP dotyczące wolności koalicji związkowej i ochrony działaczy". Monitor Prawa Pracy 2: 68-73.

Sobczyk, Arkadiusz. 2018. Podmiotowość pracy i towarowość uslug. Kraków: Wydawnictwo Uniwersytetu Jagiellońskiego.

Wujczyk, Marcin. 2019. "Nowe regulacje funkcjonowania związków zawodowych - wybrane zagadnienia”. Studia z Zakresu Prawa Pracy i Polityki Społecznej 26: 195-216.

Zalewski, Tomasz. 2012. "OPZZ skarży do Trybunału Konstytucyjnego ustawę o związkach zawodowych”. Gazeta Prawna. 29 June 2012.

Zieliński, Tadeusz. 1986. Prawo pracy. Zarys systemu. Część III. Warszawa-Kraków: Państwowe Wydawnictwo Naukowe. 